\title{
Fiscal policy: a strong macroeconomic role
}

\author{
Philip Arestis* \\ Cambridge Centre for Economic and Public Policy, Department of Land Economy, University of \\ Cambridge, UK and Department of Applied Economics V, Universidad del Pais Vasco, Spain
}

Current macroeconomics, the 'New Consensus Macroeconomics', downgrades significantly the role of fiscal policy as a stabilisation instrument of macroeconomic policy. This paper argues that fiscal policy deserves to be properly upgraded. More recent theoretical and empirical developments on the fiscal policy front are closely examined. This examination reveals that these developments lead to the conclusion that fiscal policy is not as ineffective as argued by the 'New Consensus Macroeconomics' proponents. On the contrary, it has a strong macroeconomic role. It is also the case that, in view of the 'Great Recession', financial stability has been shown to be very important in economic policy but had been ignored prior to it. The paper argues strongly that fiscal policy is actually a strong macroeconomic stabilisation instrument, especially so when it is coordinated not only with monetary policy but also and closely with financial stability policies - with such coordination-embracing income distribution. Fiscal policy should thereby be restored to its proper upgraded role in terms of economic policy. It is, therefore, high time economists and economic policymakers turned their attention more closely and seriously to this aspect and restored fiscal policy to its strong macroeconomic role.

Keywords: fiscal policy, coordination of fiscal and monetary/financial policies

JEL codes: $E 62, H 30$

\section{INTRODUCTION}

Despite the use of fiscal policy following the crisis that emerged in August 2007, which saved the world from the second 'Great Depression' and ended instead with the 'Great Recession', full faith in fiscal policy is still not there. The purpose of this paper is to argue that fiscal policy has a strong macroeconomic role. Such a role, however, can only be achieved if there is proper coordination between fiscal policy and monetary/financial stability policy. Interestingly enough, the 'Great Recession' has highlighted not only the importance of fiscal policy but also that of financial stability. Both had been downgraded prior to the 'Great Recession'. In terms of financial stability the belief in the efficiency of financial markets prevented a realistic and necessary approach to it by the supporters of the New Consensus Macroeconomics (NCM) framework. As a result, potential systemic risk was ignored and financial regulation as well as supervision 'were increasingly light-touch and reliant on self-correcting market forces' (IMF 2010b, p. 7); and completely absent in the case of the 'shadow

* I am very grateful to Malcolm Sawyer and Tom Palley for their comments and positive suggestions, which no doubt improved the paper. The usual disclaimer applies, of course. 
banking'. The focus of this contribution is on the strong macroeconomic role of fiscal policy, which is enhanced when coordinated with monetary/financial stability policies.

We proceed after this short introduction with the theoretical developments on the effectiveness of fiscal policy (section 2). Empirical developments on fiscal policy are examined in section 3 . The strong role of fiscal policy and its coordinated role with monetary/financial stability policies are discussed in section 4. A final section 5 summarises and concludes.

\section{THEORETICAL DEVELOPMENTS ON FISCAL POLICY}

We begin with the NCM theoretical developments, which have been used extensively not merely by academic economists but also by central banks around the world (see, for example, Arestis and Sawyer 2008b). This is a classic case that views fiscal policy as ineffective as an instrument of stabilisation policy. The NCM theoretical framework gives prominence to the factors that weaken fiscal policy.

\subsection{Fiscal policy within the NCM}

Fiscal policy should only rely on automatic stabilisers, but more importantly it should be concerned with broadly balancing government expenditure and taxation, effectively downgrading its importance as an active instrument of economic policy. This is a conclusion based essentially on the usual assumptions of crowding-out of private activity by government deficits and the Ricardian Equivalence Hypothesis, or the neo-Ricardian hypothesis (NRH) (see Arestis (2012) for a critique and a different view). ${ }^{1}$ Further assumptions that support the NCM fiscal policy ineffectiveness proposition include that of 'rational expectations' along with reliance on households optimising intertemporally, that of households not subjected to any liquidity constraints, and that households are able to anticipate intertemporal financial constraints. All these assumptions have the effect of weakening fiscal policy, thereby rendering it completely ineffective as a macroeconomic stabilisation instrument. ${ }^{2}$

The NCM proponents argue that an increase in government deficit, for example, would imply an increase in the future tax burden with economic agents expected to decrease their current consumption and savings in anticipation of lower future income. Labour supply would also decrease in view of the expected increase in future taxes, which would induce expectations of lower production as a result of the distorting effects of higher taxation. There are also other supply-side effects in that the increase in public employment reduces private sector labour supply, exerting an upward pressure on wages, which decreases the present discounted value of the future stream of profits. This affects investment adversely, which is also affected by higher interest rates in view of the increased deficit (the usual crowding-out effect).

A further main theoretical property of the NRH is the irrelevance of the government's financing decisions vis-à-vis taxes and debt. A fiscal expansion prompts expectations of future fiscal contractions regardless of the way financing is undertaken.

1. See, also, Tobin and Buiter (1980) and Haliassos and Tobin (1990) for early critiques of the NRH's strict assumptions.

2. In Arestis (2011 and 2012) a comprehensive critique is provided of the relevant assumptions and their implications. 
Private savings increase to compensate for the reduction in government saving, in the expectation of future tax increases, with the multiplier effect of the fiscal expansion brought to zero in the limit. Consequently, the assumption of 'rational expectations', along with the acceptance of the NRH, imply that expectational effects might outweigh the Keynesian type of multiplier effects. One can go further in that in the intertemporal budget literature, there is also a budget constraint on households such that (present value of discounted) savings and investment are equal at full-employment potential output. Then by assumption there is no room for fiscal policy since, in effect, savings at potential output equals investment at potential output (and presumably no room either for the economic forces that get the economy to potential output). This would suggest that this is a classic case of assuming what is to be proved.

A related contribution that is essentially supportive of the arguments and assumptions that relate to the fiscal policy of the NCM theoretical framework is Alesina et al. (2006). Fiscal austerity in this approach is expansionary in both the short and the long run. However, there is a recent IMF (2010a) contribution that produces results on fiscal policy that are contradictory to the results of Alesina et al. (2006). These two publications differ in terms of the terminology employed relative to the nature of the budget deficit utilised. While Alesina et al. (2006) use a cyclically adjusted measure for budget deficits, the IMF (2010a) uses a policy-driven measure. The latter study shows that fiscal policy is more effective under government expenditure financing rather than taxes. This is, of course, a result that is consistent with the typical Keynesian results on the impact of fiscal policy. Baker (2010) further suggests that a cyclically-adjusted budget deficit does not accurately distinguish between endogenous and policy-driven changes in fiscal policy. The results of Alesina et al. (2006), therefore, as well as those of Alesina and Ardagna (2009) that are not dissimilar to the ones of Alesina et al. (2006), would be rather confusing in this view (see also the study by Jayadev and Konczal (2010), which is equally critical).

A further point on the Alesina et al. (2006) contribution is the following. Let us take their argument of looking at cyclically-adjusted structural budget deficits, and compare two situations: ${ }^{3}$

(i) A structural budget deficit defined as: $G-t Y^{*}=a$, where $G$ is government expenditure, and if we label $T$ as taxes we have: $T=t Y^{*}$, whereby taxes are assumed to be related to potential output $\left(Y^{*}\right)$, where $t$ is the marginal tax rate. Also, consider another case where,

(ii) Structural budget deficit $=G^{\prime}-t^{\prime} Y^{*}=b$, with case (ii) assumed to entail a smaller deficit than case (i).

Now if position (i) is sustainable, then since $G-T=S-I+N X$, where $S$ is savings, $I$ is investment and $N X$ is net exports, we have: $S^{*}-I^{*}-N X^{*}=a$, where * after a variable signifies the value taken when the economy is at its potential output. Similarly under position (ii), in which: $S^{*}-I^{*}-N X^{*}=b$. Thus, if lowering the structural

3. A structural budget is the position when the economy is operating at some pre-defined level of output, such as the potential output, often referred to as the zero output gap. Sawyer (2012) argues that there are problems with the concept of potential output and difficulties in securing an estimate of potential output, implying that achieving a balanced structural budget is not a well-defined objective. Indeed, Arestis and Sawyer (2008a) demonstrate that for these reasons potential output should not be seen as a 'desirable' level of output, nor should it be taken as corresponding to the full employment of labour (even though it is sometimes presented as such). 
budget can actually be achieved, then it must be that there have been changes in the 'structural' propensity to save, invest and net exports. Hence, choosing situations where there have been reductions in the structural budget deficit means choosing situations where savings, investment and net exports have changed, in combination, correspondingly. Clearly these changes could only arise with a strong form of the NRH, namely the intention to reduce a structural budget deficit would be exactly matched by corresponding changes in private expenditure. A related point is that if NRH held then there would be no point in having budget deficits since private activity would be crowded out correspondingly. Putting it the other way round, if NRH held, there would not be cycles in economic activity - the financial crisis would have no effect. Since cycles in economic activity are observed, NRH is denied!

A further point is that the NCM theoretical framework rests on the assumption that savings and investment are functions of the rate of interest, and in effect only of the rate of interest. Introducing other influences in savings and investment can change the picture; notably so if a variable, which is related to economic activity, is introduced into the investment function (for example, capacity utilisation, profits), and the evidence supports such an inclusion (see Sawyer 2010). In other words, the forces at work on investment and those on savings are rather different, and there is little reason to think that there will be factors bringing savings and investment into line. There are, thus, major issues surrounding the calculation of structural budget positions, thereby creating serious problems when they are used as an objective of fiscal policy (Sawyer 2012).

\subsection{Pro-fiscal policy contributions}

Relaxing the assumptions of the theoretical model of the NCM produces favourable results for fiscal policy. An important relaxation that can be made is that of overlapping generations, which produces a short planning horizon by households implying that intertemporal smoothing of consumption is not possible (see, for example, Botman and Kumar 2006). Blinder (2006) goes further and refers to other 'unrealistic' assumptions of the NRH, such as those of long time horizons, perfect foresight, perfect capital markets and the absence of liquidity constraints. Removing such unrealistic assumptions reaffirms the effectiveness of fiscal policy.

Referring to the assumption of liquidity-unconstrained households, the evidence clearly suggests that even in developed countries up to a third of households do not have sufficient access to financial markets. In fact the assumption of liquidityconstrained households and firms is a great deal more realistic and is supported by the available evidence (Botman and Kumar 2006). Fiscal policy, then, can have positive effects on productivity growth through enhancing firms' ability to finance 'innovative investment'.

Mankiw and Weinzierl (2011) employ a typical three-equation NCM model (as, for example, does Arestis 2007) to show that only after monetary policy has exhausted its potential should fiscal policy be employed. The problem with this suggestion is that it is unclear what the expression 'monetary policy has exhausted its potential' really means. If it means that a lower actual interest rate is not possible, in the belief that the 'natural' rate of interest is not compatible with the current interest rate, then there may not be a lower floor to the interest rate, in that the actual interest rate cannot be lowered in view of the higher 'natural' rate. Also, when non-Ricardian, rule-of-thumb households are allowed in the model, the authors conclude that 'the description of the equilibrium 
closely resembles the traditional Keynesian model, but the prescription for optimal policy can differ substantially from the textbook answer' (p. 4). In effect fiscal policy does matter in this approach with non-Ricardian households.

The discussion so far assumes closed economy considerations. The case of open economies is, of course, important and could produce different results from the closed economy case. The reason is that in the open economy case, trade balance and exchange rate changes could affect the value of the fiscal multiplier. For example, expansionary fiscal policy could cause a deficit in the balance of payments. The depreciation of the exchange rate that follows, under a flexible exchange rate regime, may very well produce a balance of payments deficit - in the case of a fixed exchange rate regime the exchange rate could of course be contained. If at the same time higher interest rates ensue, capital inflows emerge, which are bound to contain the currency depreciation. All in all, the reported open economy multipliers are weaker, but certainly not negative, than in the case of a closed economy, precisely because of the partial leak abroad of the fiscal stimulus. The size of the leakage would depend crucially on a number of factors that relate to the openness of the economy. Coenen et al. (2012) refer to the cases of the US and Europe to show that fiscal multipliers in the US are larger than in Europe, simply because the latter is a more open economy with larger leakages to imports. It is important to emphasise, though, that open economy multipliers favour fiscal policy (Gravelle and Hungerford 2011). ${ }^{4}$ It should be noted, nonetheless, that the openness of the economy may well lower multipliers but of course raises the issue of the possible impact of fiscal policy in one country upon others. A further point is that the NCM is normally set in a closed economy context, and no work has been undertaken to show whether the NRH results carry over into the open economy case. The NCM, therefore, requires the assumptions of flexible exchange rates and current account balances.

\section{EMPIRICAL DEVELOPMENTS ON FISCAL POLICY}

We begin with studies that produce evidence against fiscal policy effectiveness, followed by studies that are more favourable to fiscal intervention.

\subsection{Unfavourable evidence}

Alesina and Ardagna (2009, p. 50) conclude that fiscal adjustments based on spending cuts accompanied by tax cuts are most successful. Indeed, the authors suggest, their results are relevant to the current US fiscal position of high debt-to-GDP ratio. At the same time, though, Jayadev and Konczal (2010) show that there is little evidence in the Alesina and Ardagna (2009) study of a country in their sample that reduced its deficit and its debt/GDP ratio when in slump. Gravelle and Hungerford (2011)

4. It is important to note that the relationship between fiscal policy and the exchange rate is important and needs further investigation. A recent study by Chatterjee and Mursagulov (2012) investigates the relationship between government spending, mainly on public infrastructure, and the dynamics of the real exchange rate. Government spending produces a persistent and nonmonotonic U-shaped adjustment path of the real exchange rate. Initially, depreciation emerges that continues in the short run. In the long run, the depreciation is reversed into a net long-run appreciation. Still, sharp intertemporal trade-offs are evident. The financing of government expenditure is an important factor in this respect. 
reinforce the results of Jayadev and Konczal (2010) and argue that 'Most of the fiscal adjustments in advanced economies identified by Alesina and Ardagna were neither successful nor expansionary. Furthermore, most of their successful fiscal adjustments took place during fairly favorable economic conditions' (p. 10; see also Baker 2010).

A study that makes a strong point even with the Ricardian Equivalence assumption embedded firmly in the analysis is the one by Wren-Lewis (2000). However, even with this assumption in place, it is demonstrated that fiscal policy is effective, a point strengthened by a subsequent contribution (Kirsanova et al. 2009). The additional assumption in this respect allows for the presence of cost-push shocks. Given that cost-push shocks cannot be tackled by monetary policy (see, for example, Arestis and Sawyer 2008a), fiscal policy can be used effectively not so much through its influence on aggregate demand as 'through its impact on key relative prices' (Wren-Lewis 2000, p. F489).

A study that attempts to resolve the contradiction between the typical predictions of the NCM type of theoretical models, which conclude that government expenditure has a strong negative effect on consumption, and those of the empirical literature, that conclude on a positive effect on consumption of a government expenditure change, is the study by Coenen and Straub (2005). They conclude that the evidence is not in favour of the predictions of the NCM. Coenen and Straub (op. cit.) examine the effects of fiscal policy in the case where two types of households are assumed in an extended version of the euro area Dynamic Stochastic General Equilibrium (DSGE) model, developed by Smets and Wouters (2003): Ricardian and non-Ricardian ones (as, for example, in Galí et al., 2004). ${ }^{5}$ There is actually empirical evidence that supports the contention that a significant proportion of consumers and firms are non-Ricardian in that they are not forward-looking or their behaviour is constrained (Coenen and Straub, 2005); indeed, the latter study concludes that the presence of non-Ricardian households is crucial. The quantitative impact of government spending on consumption is higher as compared to the benchmark case without non-Ricardian households. It is clear, then, that the unfavourable empirical results on fiscal policy cannot be supported. On the contrary, there is further supportive evidence of fiscal policy, as we show next.

\subsection{Favourable evidence}

A number of studies advocate greater emphasis on fiscal policy as a key economic tool in macroeconomic stabilisation. Romer and Romer (2010) is an example where a multiplier of roughly 3 is found for the US after 3 years of the fiscal change. Two recent IMF studies are also favourable to fiscal policy. The first (IMF 2012b) suggests that 'In the current recessionary context, the negative impact of fiscal adjustment on activity can be expected to be large, as confirmed by new work on the size of fiscal multipliers during periods of weak economic activity' (p. ix). The second (Baunsgaard et al. 2012) produces results summarised by IMF (2012b) as 'fiscal multipliers - which measure the ratio of a change in output to the discretionary change in the fiscal deficit that caused it - can for many reasons be expected now to be above the average multipliers identified

5. Ricardian households are those that behave in an optimizing, fully forward manner, by trading in asset and other markets and are, thus, able to smooth consumption over time. NonRicardian households follow non-optimizing simple rules of thumb (they do not optimize intertemporally or intratemporally), cannot and do not participate in asset markets, and they merely consume their net-of-tax disposable income. 
in earlier studies' (p. 15). Coenen et al. (2012) provide a summary of further studies on the same theme where significant fiscal policy multiplier effects are reported.

In Arestis and Sawyer (2012a), the stock/flow consistency model as developed at the Levy Economics Institute of Bard College is utilised to examine the impact of fiscal policy. The model is shocked by increasing government expenditure financed through borrowing, taxation and printing high-powered money. The case where the financing of an increase in government expenditure is undertaken through borrowing produces an impact multiplier, which is quite substantial in the first period, but subsequent crowding-out effects, emanating possibly from private sector expenditure, are not strong enough to restrict the positive impact. Ultimately, some increase in imports restricts the increase in GDP and produces the long-run multiplier at the steady-state of 2.28. This value of the long-run dynamic multiplier is quite high compared to the findings of many other studies on fiscal multipliers. In the case of an increase in government expenditure, which is financed by increases in government receipts, the dynamic multipliers, both the impact and the long-run ones, are lower than in the case just discussed. This is not surprising given that the effects of the increase in government expenditure are to a large extent outweighed by the simultaneous increase in taxes with opposite effects. The case of the increase in government expenditure, financed through increases in high-powered money, produces an impact multiplier that is unsurprisingly the same as in the case of the financing undertaken through borrowing. The long-run multiplier is, however, significantly lower at 0.44 . This is a low long-run multiplier, which surprisingly is the lowest of all long-run multipliers discussed above.

The results of Gravelle and Hungerford (2011), which provide a summary of fiscal policy multipliers of a number of studies, are not dissimilar to the ones of Arestis and Sawyer (2012a). The multipliers reported in Gravelle and Hungerford (2011) vary as follows:

multipliers of 1.0 to 2.5 for government spending and transfers to the states for infrastructure, and

0.7 to 1.8 for transfers to the states for other purposes ... For direct transfers to individuals (who have low incomes) the multipliers were between 0.8 and 2.1. Payments to retirees (largely Social Security beneficiaries) were 0.3 to 1.0. For taxes, tax cuts for lower- and middle-income taxpayers (mainly those claiming the making work pay tax credit) were 0.6 to 1.5 , while the increase in the alternative minimum tax exemption for higher-income individuals was 0.2 to 0.6. Business tax cuts, mostly of a cash flow nature, were 0.0 to 0.4 . (p. 6)

Mountford and Uhlig (2009) report even higher fiscal multipliers with the maximum value of five. An IMF study (Baum et al., 2012) examines whether there is a difference in multipliers in expansions and contractions. This study examines this possibility in the case of six out the G7 economies to conclude that average fiscal multipliers are larger in contractions than in expansions. This result is more prominent in the case of spending multipliers with the revenue multipliers not as high. Auerbach (2012), Auerbach et al. (2010) and Auerbach and Gorodnichenko (2012) are studies that assess the effectiveness of fiscal policy, spawned by the Great Recession, which also conclude that the size of fiscal multipliers differs in recessions and expansions. Auerbach and Gorodnichenko (2012), in particular, use regime-switching, structural vector autoregression (SVAR), models and control for expectations, and also conclude that government expenditure multipliers differ between recessions and expansions. In the case of the US economy, the derived multipliers vary from 1 to 1.5 in recessions and 0 to 0.5 in expansions. ${ }^{6}$

6. Blanchard and Perotti (2002) argue that in studying the quantitative impact of fiscal policy, the Structural VAR (SVAR) approach is more appropriate than large-scale econometric models or reduced-forms. Employing post-war US data along with SVAR, the authors conclude that 
Another recent contribution, Coenen et al. (2012), is also very supportive of fiscal policy as a stabilisation instrument. A number of features are present in this study, of which the ones relevant to our analysis are: the highly detailed fiscal policy blocks embedded in the analysis, which permit the study to utilise a wide set of fiscal instruments. Also, the models utilised incorporate some empirically relevant channels that may significantly impact the transmission of fiscal shocks. Coenen et al. (op. cit.) suggest that, "rather than assuming that all households are Ricardian "permanent income" consumers', they specify that 'a significant fraction of households is liquidityconstrained, or follows rule-of-thumb behaviour' (p. 24). The Spilimbergo et al. (2008) study goes a step further to suggest that:

a fiscal stimulus should be timely (as there is an urgent need for action), large (because the drop in demand is large), lasting (as the recession will likely last for some time), diversified (as there is uncertainty regarding which measures will be most effective), contingent (to indicate that further action will be taken, if needed), collective (all countries that have the fiscal space should use it given the severity and global nature of the downturn), and sustainable (to avoid debt explosion in the long run and adverse effects in the short run). The challenge is to provide the right balance between these sometimes competing goals - particularly, large and lasting actions versus fiscal sustainability. (p. 2)

Clearly fiscal policy does matter, which leads to the obvious question of the precise and proper role of fiscal policy as a stabilisation instrument of macroeconomic policy. We discuss this issue in section 4.

\section{THE STRONG ROLE OF FISCAL POLICY}

The above analysis clearly demonstrates that fiscal policy does have a significant role to play as a macroeconomic stabilisation instrument. We discuss in this section how this strong role of fiscal policy might be implemented. We look at some theoretical propositions to begin with, followed by relevant empirical findings, and complete the discussion by looking at recent developments that should frame the future role of fiscal policy.

\subsection{Theoretical propositions}

We begin by making it clear that fiscal policy should not be implemented in isolation to monetary policy. We may refer to the case of fiscal expansion to make the point. The impact of fiscal policy on output in this case is considerably higher and more persistent when there is monetary accommodation. If such accommodation is not present, risks can arise, in that the impact of fiscal policy may not be the desirable one, in which case one policy forces the other to adjust, thereby limiting significantly the

spending multipliers for consumption and output are anything between one third and unity. Perotti (2012) concludes that higher tax multipliers than the ones in Blanchard and Perotti (2002) and Favero and Giavazzi (2012) are in order. Perotti (2012) also concludes that there is no evidence of taxation anticipated effects; there are, thus, liquidity constraints (see also Mertens and Ravn 2012). Another contribution (Richter and Walker 2012) is concerned with the issue of fiscal foresight. It concludes that 'the extent to which a standard DSGE model estimated with time-invariant news may incorrectly imply that foresight is not relevant for explaining business cycle dynamics' (p. 117). 
margin of the effectiveness of fiscal policy. It is thus important that fiscal policy should be properly coordinated with monetary policy. This is vital, in that monetary policy reaction can play a key role in the effectiveness of fiscal policy. When monetary and fiscal policies are consistent so that their impact on aggregate demand is cumulative, and not offsetting, the overall impact is higher than it would otherwise be. In this sense, the study of Linnemann and Schabert (2003), where a model of wage and price stickiness is utilised, is important in that it demonstrates that fiscal policy can affect output significantly if the monetary authority does not react aggressively to output changes.

A more concrete channel of fiscal expansion has been suggested by Eggertsson (2006). This channel works via inflation expectations. Fiscal expansion enhances expectations about future inflation, and, provided the central bank collaborates with the fiscal authority, the real rate of interest is reduced, which stimulates spending. Further spending is inevitable as a result of healthy expectations of future income emerging. It follows that macroeconomic stability should be the joint responsibility of the monetary and fiscal authorities. Destabilising behaviour by one authority can be offset by an appropriate stance of the other authority. What would help in this approach is for the monetary authority to trade off some inflation for lower unemployment. For, then, a fiscal stimulus that increases inflationary pressures (or at least reduces deflationary pressures), with a monetary authority that keeps constant nominal interest rates, lowers real interest rates, thereby giving rise to further increases in consumption and investment expenditures. Also, a lower real interest rate causes the real exchange rate to depreciate, which can also play a role in stimulating aggregate demand.

Under current arrangements of independent central banks around the world, coordination of fiscal and monetary policy does not necessarily imply that the respective authorities need to lose their 'independence'. In such a case, though, both fiscal and monetary authorities should have a common objective, for example maximisation of social welfare, without losing their 'independence' (Eggertsson 2006). Both authorities would have to agree on the variables to be included in the social welfare function and the nature of trade-offs between the objectives (see also Wren-Lewis 2000). But it still raises the issue of what happens in the case of disagreement between the two authorities over, for example, the state of the economy, or the nature of trade-offs between objectives, such as the weights to be placed on inflation and unemployment. It must be readily recognised that these are issues that would have to be faced seriously. Under current arrangements there is a sense in which the monetary authorities can express their disapproval of the fiscal stance by, for example, raising interest rates if they think fiscal policy is too loose. Under coordination, the monetary authority would have to adhere to the agreed fiscal stance.

\subsection{Empirical verification}

The empirical evidence is very supportive of the theoretical propositions just proposed. Eggertsson (2006), utilising a calibrated model not dissimilar in substance to the NCM, reaches the conclusion that, under fiscal and monetary policy coordination, fiscal multipliers are higher than when no policy coordination prevails; indeed, they are bigger than those found in the traditional Keynesian literature. Two types of fiscal multipliers are reported in Eggertsson (op. cit.): a real spending multiplier, where government consumption is raised but holding the budget balanced; and a deficit multiplier, where deficit spending increases. These fiscal multipliers are derived under 
two scenarios: when fiscal and monetary policies are coordinated; and when there is no policy coordination.

The fiscal policy multiplier under coordination is 3.4 in the case of the real spending multiplier, and 3.8 under the deficit spending multiplier. When no policy coordination is present - that is, when the central bank is 'goal independent' - the real spending multiplier is unchanged, while the deficit spending multiplier is zero. This important difference in fiscal multipliers, when coordination is present in relation to those where coordination is absent, is explained by the expectations channel as discussed above. Eggertsson (2006) suggests that:

Without coordination deficit spending has no effect so that the multiplier is zero. The reason is that deficit spending works entirely through expectations about future interest rate policy (i.e. through the expectation of higher future money supply). Under coordinated policy deficit spending implies higher nominal debt, and optimal monetary policy under discretion implies that this will increase inflation expectations, because higher nominal debt makes a permanent increase in the money supply incentive compatible. Without coordination, however, this link is broken because the central bank has a narrow objective that does not take into account the fiscal consequences of its actions. Instead there is strong deflation bias of discretionary monetary policy which is severely suboptimal when there are deflationary shocks. (p. 5$)^{7}$

A study that reaches similar conclusions is Freedman et al. (2009). This study utilises the IMF macroeconomic DSGE model, which includes non-Ricardian households, to conclude that:

the multipliers of a two-year fiscal stimulus package range from 1.3 for government investment to 0.2 for general transfers, with targeted transfers closer to the upper end of that range and tax cuts closer to the lower end. In the presence of monetary accommodation ... multipliers are up to twice as large, as accommodation lowers real interest rates, which in turn has a positive effect on corporate balance sheets and therefore on the external finance premium. (p. 26)

Davig and Leeper (2009), utilising a DSGE model, reach similar conclusions. This study concentrates on the experience of the 'Great Recession' when fiscal and monetary policies were used jointly in an effort to stimulate aggregate demand. The usual DSGE assumptions are utilised, with government expenditure treated as an exogenous variable. The study clearly concludes that coordination of the two policies provides stronger results than otherwise:

With the calibrated model in hand, we simulate the impacts of the government spending component of the American Recovery and Reinvestment Act of 2009 under alternative monetaryfiscal regimes. When monetary policy is active and fiscal policy is passive, the fiscal stimulus creates a modest expansion in output and it raises inflation and real interest rates, while government debt and taxes rise substantially and persistently. On the other hand, passive monetary policy and active fiscal policy generate an appreciably larger boom in output and consumption, and a significantly larger run-up in inflation, while rapidly reducing the real value of government liabilities. (p. 5)

7. A relevant study by Woodford (2011) suggests that under conditions of 'zero-bound' nominal rate of interest, the size of fiscal policy in excess of unity is possible. This can happen only when the task of monetary policy to fill the output gap generated by the falling real rate of interest, due to inflationary pressures, is undertaken by fiscal policy. 
Eggertsson (2011) utilises a two-state Markov-switching framework to examine fiscal multipliers when monetary policy responds to the fiscal policy action, and when it does not, as in the case of a zero lower bound. The conclusion is that fiscal multipliers are about five times higher at the zero lower bound than on the other more normal occasions.

Employing a number of structural DSGE models, ${ }^{8}$ and using several different fiscal instruments, such as government spending measures, tax and transfer changes, large fiscal multipliers are established, especially so in the case of spending and targeted transfers. Coenen et al. (2012) find that the stimulative effects of fiscal policy are reduced, but are still significant when the increase in government expenditure is permanent, a conclusion that corroborates the results of Cogan et al. (2010). All in all, the results of the Coenen et al. (2012) study suggest that 'a strong case for using targeted transfers to mitigate recessions, at least to the extent that it may be more difficult at the margin to inject and withdraw stimulus through adjusting government expenditure' (p. 25) is made. Fiscal policy, though, is most effective when monetary policy is accommodative; and, to quote Coenen et al. (op. cit):

With no monetary accommodation, the inflation pressures lead to an upward movement in real interest rates and thereby offset, in part, the effects of the fiscal stimulus on GDP. In contrast, with monetary accommodation and nominal interest rates held constant, the increases in inflation give rise to decreases in real interest rates. As a result accommodative monetary policy complements the fiscal policy stimulus and intensifies its effects on real GDP. (p. 51)

\subsection{Further policy coordination possibilities}

The 'Great Recession' has highlighted the importance of financial stability, which had been ignored prior to it, mainly because of the firm belief and emphasis on the "efficient market hypothesis' (EMH); namely that all unfettered markets clear continuously, thereby making disequilibria, such as bubbles, highly unlikely (IMF 2012a; $2010 \mathrm{~b}$ ). As a result, the role of financial stability and its policy implications were downplayed significantly. The point remains, however, that one of the main operations of any Central Bank should be directed towards financial stability (see Palley 2006, pp. 250-251). ${ }^{9}$ The events leading to the 'Great Recession' testify to this important requirement. As a result, financial stability has attracted renewed interest and focus as an instrument of monetary policy. The IMF (2010b) suggestion that financial stability in the form of both microprudential and macroprudential policies is the way forward. The same publication goes further to suggest that if the current low interest rates were to produce excessive risk-taking or bubbles, these should be addressed through macroprudential policies mainly and not only through interest rate policy measures.

A few examples of the recent policy interest in financial stability should make the point (Arestis and Sawyer 2012b). The UK Banking Act 2009, whose purpose is

8. The models utilised are those developed at the Board of Governors of the Federal Reserve System (two models), the European Central Bank, the IMF, the European Commission, the Organisation for Economic Co-operation and Development (OECD), and the Bank of Canada. 9. Palley (2006) argues that inflation or nominal income targeting are insufficient means of economic policy in view of the possible asset price and debt bubbles they are likely to produce (see also Arestis and Karakitsos 2011). Angeriz and Arestis (2008) also argue with relevant evidence that inflation targeting was not the cause of the price stability experienced prior to the Great Recession. 
'to address the situation where all or part of the business of a bank has encountered, or is likely to encounter, financial difficulties' with the 'objective of the Bank [of England] shall be to contribute to protecting and enhancing the stability of the financial systems of the United Kingdom (the "Financial Stability Objective")', ${ }^{10}$ is one such example. Further examples include: the US Dodd-Frank Act of July 2010, the UK Independent Commission on Banking (ICB; known as the Vickers Report) of September 2011, and the Basle III proposals and others. Although, as argued in Arestis and Sawyer (op. cit.), 'radical' measures aiming to 'increase stability and competition in the financial sector have been bypassed' (p. 158), still these measures have highlighted the importance and need of financial stability policies and the need to establish appropriate polices. BIS (2011) also makes the point when it suggests that 'we need a stability framework in which monetary, fiscal and prudential policy work together to build a robust and stable macroeconomic and financial system that will make the next crisis both less likely and less severe' (p. 3).

With the objective of financial stability, the Central Bank would become more like a Central Financial Agency (CFA). It would be responsible for policies, which seek to influence the credit and lending policies of the full range of financial institutions. Our current contribution in this context is to argue the case for full coordination of both monetary and financial stability policies with fiscal policy; we would go one step further and suggest that discretion is as important in applying them.

Such coordination should also embrace another important dimension. Recent experience has shown that distribution of income, if not tackled, can lead to crisis, as was the case with the 'Great Recession' for example. Distribution of income from wages to profits, especially to the top end of the financial sector, was one of the main causes of the 'Great Recession' (Palley 2011 [2009]; Arestis and Karakitsos 2011; and see also Rajan 2010). We have also argued in Arestis and Sawyer (2011) for the importance of accounting 'distributional effects' in both economic theory and policy, which have been fatally ignored recently (see also Hein and Truger 2011, and Van Treeck and Sturn 2012).

Our proposal of coordination of fiscal policy with monetary/financial stability policies should also be geared towards reducing income inequality. Such reduction affects the level of demand in the economy through a higher wage share and a lower profits share. Sawyer (2010) gives examples to illustrate the case:

if the wage share were say 5 percentage points higher, and there is a difference in the marginal propensity to consume between wages and profits of say 0.3 , then savings would be lower by 1.5 percent of GDP. A redistribution of income from the top two deciles to the bottom four deciles of 10 percent of earnings - that is 6 to 7 per cent GDP, and the marginal propensity to consume difference of 0.2 , a further 1.2 to 1.4 per cent; these two, rounded up to 3 per cent of GDP would solve much of the budget deficit problem. The shift from profits to wages in the first example would be the same order of magnitude (but in the opposite direction) as that observed in industrialised countries such as Germany over the past decade. The second example similarly would amount to the reversal of the inequality changes in the UK over the past three decades. (p. 42)

These examples make the case for policies to tackle income distribution, which should be at the centre of the coordination of fiscal with monetary/financial stability policies as argued in this paper.

10. The details on the UK Banking Act of 2009 and the quotes in the text are available at: http://www.opsi.gov.uk/acts/acts2009/ukpga_20090001_en_1. 


\section{SUMMARY AND CONCLUSIONS}

We have argued in this paper that, unlike the relevant propositions of the NCM theoretical framework, fiscal policy is an effective instrument for regulating the level of aggregate demand. We have examined this conclusion through both theoretical and empirical considerations to conclude that fiscal policy is a key component of any macroeconomic framework alongside monetary/financial policy. This conclusion is supported by a further suggestion, namely coordination of fiscal and monetary/financial stability policies. In doing so, the relevant authorities should employ a great deal of discretion in the application of this coordination. It is also of great importance that the relevant authorities have a common objective; maximisation of social welfare is one such relevant common objective.

The inevitable overall conclusion of this paper is two-fold. The first is that fiscal policy does have a strong macroeconomic role to play in the conduct of economic policy. Second, coordination of fiscal and monetary/financial stability policies in a discretionary manner is the best way forward in terms of macroeconomic stabilisation. In this context, the often neglected objective of income distribution should become one of the main objectives of such coordination.

Finally, it is to be noted that there are 'old' issues that strengthen fiscal policy, such as the existence of liquidity trap, and also views that call for larger budget deficits now (Krugman 2012). There are also the meaningful implementation, institutional and political economy issues surrounding fiscal policy. All these are very pertinent issues, which, however, are not addressed in the current paper. They do, nonetheless, deserve a great deal more attention by political and policy economists. Whilst we agree with these issues, it is important to reiterate the point that this paper argues for more permanent use of fiscal policy to stabilise the economy.

\section{REFERENCES}

Alesina A. and Ardagna, S. (2009), 'Large Changes in Fiscal Policy: Taxes Versus Spending', NBER Working Paper No 15438, Washington, DC: National Bureau of Economic Research. Alesina, A., Ardagna, S. and Trebbi, F. (2006), 'Who Adjusts and When? The Political Economy of Reform', IMF Staff Papers V, 53 Special Issue, Washington, DC: International Monetary Fund.

Angeriz, A. and Arestis, P. (2008), 'Assessing Inflation Targeting Through Intervention Analysis', Oxford Economic Papers, 60(2), 293-317.

Arestis, P. (2007), 'What is the New Consensus in Macroeconomics?', in P. Arestis (ed.), Is There a New Consensus in Macroeconomics?, Houndmills, Basingstoke: Palgrave Macmillan.

Arestis, P. (2011), 'Keynesian Economics and the New Consensus in Macroeconomics', in E. Hein and E. Stockhammer (eds), A Modern Guide to Keynesian Macroeconomics and Economic Policies, Cheltenham: Edward Elgar, pp. 88-111.

Arestis, P. (2012), 'Fiscal Policy: Time for the Renaissance of Keynesianism', Wirtschaftswissenschaftliche Tagungen der AK-Wien, Forthcoming.

Arestis, P. and Karakitsos, E. (2011), 'An Analysis of the Causes of the "Great Recession" and Some Policy Implications', in T. Niechoj, Ö. Onaran, E. Stockhammer, A. Truger and T. van Treeck (eds), Stabilising an Unequal Economy? Public Debt, Financial Regulation, and Income Distribution, Marburg: Metropolis-Verlag, pp. 63-80.

Arestis, P. and Sawyer, M. (2008a), 'A Critical Reconsideration of the Foundations of Monetary Policy in the New Consensus Macroeconomics Framework', Cambridge Journal of Economics, 32(5), 761-779. 
Arestis, P. and Sawyer, M. (2008b), 'Are the European Central Bank and Bank of England Macroeconomic Models Consistent with the New Consensus in Macroeconomics?', Ekonomia, 11(2), 51-68.

Arestis, P. and Sawyer, M. (2011), 'Economic Theory and Policies: New Directions After NeoLiberalism', in P. Arestis and M. Sawyer (eds), New Economics as Mainstream Economics, Annual Edition of International Papers in Political Economy, Houndmills, Basingstoke: Palgrave Macmillan.

Arestis, P. and Sawyer, M. (2012a), 'The Effectiveness of Fiscal Policy in the Stock/Flow Levy Institute's Model', in D.B. Papadimitriou and G. Zezza (eds), Contributions in Stock-Flow Modelling: Essays in Honour of Wynne Godley, Houndmills, Basingstoke: Palgrave Macmillan.

Arestis, P. and Sawyer, M. (2012b), 'The "New Economics" and Policies for Financial Stability', International Review of Applied Economics, 26(2), 147-160.

Auerbach, A.J. (2012), 'The Fall and Rise of Keynesian Fiscal Policy', Working Paper, University of California, Berkley, May.

Auerbach, A.J., Gale, W.G. and Harris, B.H. (2010), 'Activist Fiscal Policy', Journal of Economic Perspectives, 24(4), 141-164.

Auerbach, A.J. and Gorodnichenko, Y. (2012), 'Measuring the Output Responses to Fiscal Policy', American Economic Journal: Economic Policy, 4(2), 1-27.

Baker, D. (2010), 'The Myth of Expansionary Fiscal Austerity', Center for Economic and Policy Research, Washington, DC. Available at: http://www.cepr.net/index.php/publications/ reports/the-myth-of-expansionary-fiscal-austerity.

Baum, A., Poplawski-Ribeiro, M. and Weber, A. (2012), 'Fiscal Multipliers and the State of the Economy', IMF Working Paper, Washington, DC: International Monetary Fund, Forthcoming.

Baunsgaard, T., Mineshima, A., Poplawski-Ribeiro, M. and Weber, M. (2012), 'Fiscal Multipliers', in C. Cottarelli, P. Gerson, and A. Senhadji (eds), Post-crisis Fiscal Policy, Washington, DC: International Monetary Fund, Forthcoming.

BIS (Bank for International Settlements) (2011), 'Fiscal Policy and its Implications for Monetary and Financial Stability', BIS Papers, No. 59, December, Basel, Switzerland: Bank for International Settlements. Available at: http://ssrn.com/abstract=2002654.

Blanchard, O. and Perotti, R. (2002), 'An Empirical Characterization of the Dynamic Effects of Changes in Government Spending and Taxes on Output', Quarterly Journal of Economics, 117(2), 1329-1368.

Blinder, A. (2006), 'The Case Against Discretionary Fiscal Policy', in R.W. Kopcke, G.M.B. Tootell and R.K. Triest (eds), The Macroeconomics of Fiscal Policy, London: MIT Press, pp. 25-61.

Botman, D. and Kumar, M.S. (2006), 'Fundamental Determinants of the Effects of Fiscal Policy', IMF Working Paper 06/72, Washington, DC: International Monetary Fund.

Chatterjee, S. and Mursagulov, A. (2012), 'Fiscal Policy and the Real Exchange Rate', IMF Working Paper, WP/12/52, Washington, DC: International Monetary Fund.

Coenen, G., Erceg, C.J., Freeman, C., Furceri, D., Kumhof, M., Lalonde, R., Laxton, D., Lindé, J., Mourougane, A., Muir, D., Mursula, S., de Resende, C., Roberts, J., Roeger, W., Snudden, S., Trabandt, M. and In't Veld, J. (2012), 'Effects of Fiscal Stimulus in Structural Models', American Economic Journal: Macroeconomics, 4(1), 22-68.

Coenen, G. and Straub, R. (2005), 'Does Government Spending Crowd in Private Consumption? Theory and Empirical Evidence for the Euro Area', IMF Working Paper 05/159, Washington, DC: International Monetary Fund. (Also ECB Working Paper Series No 513, August, Frankfurt: European Central Bank.)

Cogan, J.F., Ceik, T., Taylor, J.B. and Wieland, V. (2010), 'New Keynesian versus Old Keynesian Government Spending Multipliers', Journal of Economic Dynamics and Control, 34(3), 281-295.

Davig, T. and Leeper, E.M. (2009), 'Monetary-Fiscal Policy Interactions', CAEPR Working Paper No. 010-2009. Available at: http://ssrn.com/abstract=1456355.

Eggertsson, G.B. (2006), 'Fiscal Multipliers and Policy Coordination', Federal Reserve Bank of New York Staff Reports, No. 241, New York: Federal Reserve Bank of New York. 
Eggertsson, G.B. (2011), 'What Fiscal Policy is Effective at Zero Interest Rates?', in D. Asemoglu and M. Woodford (eds), NBER Macroeconomics Annual 2010, Vol. 25, Chicago: Chicago University Press, pp. 59-112.

Favero, C. and Giavazzi, F. (2012), 'Measuring Tax Multipliers: The Narrative Method in Fiscal VARs', American Economic Journal: Economic Policy, 4(2), 69-94.

Freedman, C., Kumhof, M., Laxton, D., Muir, D. and Mursula, S. (2009), 'Fiscal Stimulus to the Rescue? Short-run Benefits and Potential Long-run Costs of Fiscal Deficits', IMF Working Paper WP/09/255, Washington, DC: International Monetary Fund.

Galí, J., López-Salido, J.D. and Vallés, J. (2004), 'Understanding the Effects of Government Spending on Consumption', ECB Working Paper Series No 339, Frankfurt: European Central Bank.

Gravelle, J.G. and Hungerford, T.L. (2011), 'Can Contractionary Fiscal Policy be Expansionary?', Congressional Research Service, Report for Congress, R41849, Washington, DC, 6 June.

Haliassos, M., and Tobin, J. (1990), 'The Macroeconomics of Government Finance', in B.M. Friedman and F.H. Hahn (eds), Handbook of Monetary Economics, Volume 2, NorthHolland: Amsterdam, pp. 889-959.

Hein, E. and Truger, A. (2011), 'Finance-Dominated Capitalism in Crisis: The Case for a Keynesian New Deal at the European and the Global Level', in P. Arestis and M. Sawyer (eds), New Economics as Mainstream Economics, Basingstoke: Palgrave Macmillan.

IMF (International Monetary Fund) (2010a), 'Will it Hurt? Macroeconomic Effects of Fiscal Consolidation', Economic Outlook, Chapter 3, Washington, DC: International Monetary Fund.

IMF (International Monetary Fund) (2010b), 'Central Banking Lessons from the Crisis', Monetary and Capital Markets Department, Washington, DC: International Monetary Fund, 27 May.

IMF (International Monetary Fund) (2012a), 'Fiscal Policy and the Real Exchange Rate', IMF Working Paper WP/12/52, Washington, DC: International Monetary Fund.

IMF (International Monetary Fund) (2012b), 'Balancing Fiscal Risks', Fiscal Monitor, World Economic and Financial Surveys, April, Washington, DC: International Monetary Fund, Forthcoming.

Jayadev, A. and Konczal, M. (2010), 'The Boom not the Slump: The Right Time for Austerity', Roosevelt Institute, Washington, DC. Available at http://www.rooseveltinstitute.org/sites/all/ files/not_the_time_for_austerity.pdf.

Kirsanova, T., Leith, C. and Wren-Lewis, S. (2009), 'Monetary and Fiscal Policy Interaction: The Current Consensus Assignment in the Light of Recent Developments', Economic Journal (November), F482-F496.

Krugman, P. (2012), End this Depression Now!, London: W.W. Norton \& Company Ltd.

Linnemann, L. and Schabert, A. (2003), 'Fiscal Policy in the New Neoclassical Synthesis', Journal of Money, Credit and Banking, 35(6), Part 1, 911-929.

Mankiw, N.G. and Weinzierl, M.C. (2011), 'An Exploration of Optimal Stabilization Policy', NBER Working Paper No. 17029, Washington, DC: National Bureau of Economic Research. Available at: http://www.nber.org/papers/w17029.

Mertens, K. and Ravn, M.O. (2012), 'Empirical Evidence on the Aggregate Effects of Anticipated and Unanticipated US Tax Policy Shocks', American Economic Journal: Economic Policy, 4(2), 145-181.

Mountford, A. and Uhlig, H. (2009), 'What are the Effects of Fiscal Policy Shocks?', Journal of Applied Econometrics, 24(6), 960-992.

Palley, T.I. (2006), 'Monetary Policy in an Endogenous Money Economy', in P. Arestis and M. Sawyer (eds), A Handbook of Alternative Monetary Economics, Cheltenham: Edward Elgar, pp. 242-257.

Palley, T.I. (2011), 'America's Flawed Paradigm: Macroeconomic Causes of the Financial Crisis and Great Recession', Empirica, 38(1), 3-17. (Originally published as 'America's Exhausted Paradigm: Macroeconomic Causes of the Financial Crisis and Great Recession', New America Foundation, Washington, DC, July 2009.) 
108 Review of Keynesian Economics, Inaugural Issue

Perotti, R. (2012), 'The Effects of Tax Shocks on Output: Not So Large, But Not Small Either', American Economic Journal: Economic Policy, 4(2), 214-237.

Rajan, R.G. (2010), Fault Lines: How Hidden Fractures Still Threaten the World Economy, Princeton and Oxford: Princeton University Press.

Richter, A.W. and Walker, T.B. (2012), 'Quantitative Effects of Fiscal Foresight', American Economic Journal: Economic Policy, 4(2), 115-144.

Romer, C.D. and Romer, D.H. (2010), 'The Macroeconomic Effects of Tax Changes: Estimates Based on a New Measure of Fiscal Shocks', American Economic Review, 100(3), 763-801.

Sawyer, M. (2010), 'Budget Deficits and Reductions in Inequality for Economic Prosperity: A Kaleckian Analysis', Revista LEBRET, No 2, 31-44.

Sawyer, M. (2012), 'The Contradictions of Balanced Structural Government Budgets', in H. Herr, T. Niechoj, C. Thomasberger, A. Truger, and T. van Treeck (eds), From Crisis to Growth? The Challenge of Imbalances and Debt, Marburg: Metropolis-Verlag.

Smets, F. and Wouters, R. (2003), 'An Estimated Stochastic Dynamic General Equilibrium Model of the Euro Area', Journal of the European Economic Association, 1(4), 1123-1175.

Spilimbergo, A., Symansky, S., Blanchard, O. and Cottarelli, C. (2008), 'Fiscal Policy for the Crisis', IMF Staff Position Note, SPN/08/01, December 29, Washington, DC: International Monetary Fund.

Tobin, J. and Buiter, W.H. (1980), 'Debt Neutrality: A Brief Review of Doctrine and Evidence', in George M. von Furstenberg (ed.), Social Security Versus Private Saving, Cambridge, MA: Ballenger Publishing Co., pp. 39-63.

Van Treeck, T. and Sturn, S. (2012), 'Income Inequality as a Cause of the Great Recession? A Survey of the Current Debates', IMK Working Paper, 12 April, Düsseldorf: Institut für Makroökonomie und Konjunkturforschung (IMK).

Woodford, M. (2011), 'Simple Analytics of the Government Expenditure Multiplier', American Economic Journal: Macroeconomics, 3(1), 1-35.

Wren-Lewis, S. (2000), 'The Limits to Discretionary Fiscal Stabilization Policy', Oxford Review of Economic Policy, 16, 92-105. 